\title{
A Study on the Efficiency and Countermeasures of Network-Based Autonomous Learning Platform for Vocational College English Learners
}

\author{
Liping JIANG ${ }^{1}$ \\ 1School of Business and Foreign Studies, Guangdong Mechanical \&Electrical \\ Polytechnic, Guangzhou, China \\ 2School of Social Sciences and Humanities, University College Sedaya International, \\ Kuala Lumpur, Malaysia
}

\begin{abstract}
This paper investigates the efficiency of 289 vocational college English learners using the network-based autonomous learning platform in Guangdong province in China. The results show that learners have a positive attitude toward the network-based extracurricular English autonomous learning, and learners with different English foundation have different requirements for extracurricular online autonomous learning. This paper puts forward some countermeasures on how to make full use of the network-based extracurricular English autonomous learning.
\end{abstract}

Keywords. Vocational college English learners, network autonomous learning platform, using efficiency, countermeasures

\section{Introduction}

With the continuous development of modern education and information technology, autonomous learning based on computer and network has gradually become a teaching assistant mode. "Regulations for Teaching College English Curriculum" (2007) puts forward that "a lot of advanced information technology should be used to develop and construct various courses based on network and computer".[1] In order to adapt to the new situation of the development of higher vocational education in China, deepen the teaching reform, improve the teaching quality, and meet the needs of the state and society for the cultivation of higher vocational talents in the new era, the document of The basic requirements for English Teaching in Higher Vocational Education (Trial Implementation) and The outline of the national medium and long term education reform and development plan (2010-2020) are issued. The Guidance of the two documents clearly puts forward the requirements of cultivating digital information competency, and clearly proposes that learners' autonomous learning ability should be enhanced in vocational college English [2]. English autonomous learning based on modern information technology has become a hot topic in the construction and research of higher Vocational English course in college. Network-based autonomous learning platform

\footnotetext{
${ }^{1}$ Corresponding author: 1531447813@qq.com
} 
model is gradually accepted by the majority of college teachers and learners, and has been used in assisting teaching. Many powerful publishing institutions in China have also launched online courses based on teaching materials; Language testing equipment suppliers are actively developing Network-based Autonomous Learning Platform; Some colleges and universities are also investing greatly in the construction of Network-based Autonomous Learning Environment with school-based characteristics. The construction and application of network-based autonomous learning platform will be one of the key research directions of Vocational College English autonomous learning in the future. However, at the same time, due to the current Chinese network-based autonomous learning platform is still in the early stage of development, learning content, management mode and self-learning mode are still in the initial phase of development, therefore, there are many problems to be solved.

\section{Research background}

As an indispensable part of higher education in China, higher vocational colleges shoulder the mission of cultivating professional and technical talents. In 2017, According to the document of The list of national colleges and universities issued by the Ministry of Education in China, the level of a higher education in China can be divided into undergraduate universities and higher vocational colleges (2017, Ministry of Education in China). As the pioneer of China's reform and opening up, Guangdong Province is one of China's most economically developed provinces. The number and teaching quality of higher vocational colleges rank at the forefront of China. According to the national vocational college professional setting management and public information, the service platform data of January 2020, there are 89 higher vocational colleges in Guangdong province. Vocational college English is a compulsory public course for non-English majors in the vocational colleges, which will open for them to study at the first year of college. Vocational college English learners are from both liberal arts and science. However, the academic performance of learners in vocational colleges is lower than those from undergraduate universities and colleges due to the different level of higher education, therefore, the majority of vocational college learners' English foundation is relatively poor. Therefore, it is more necessary to make full use of the advantages of blended learning and fully improve learners' adaptability of blended learning to improve the efficiency of English learning.

Can network-based autonomous learning platform promote vocational college English learners' autonomous learning? What factors restrict the autonomous learning ability of vocational college English learners? What should teachers do for learners' autonomous learning? What is the current status of vocational college English learners' autonomous learning ability? For those problems, Chinese domestic scholars have conducted in-depth research and discussion. Professor Zhu (2011) investigated the current situation of college learners' English autonomous learning, and concluded that learners have certain English autonomous learning ability, but there are also some problems. He proposed that the learners should be trained and guided in the sense of autonomous learning, learning strategies and learning methods.[3] Professor Guo (2008) discussed the guiding role of teachers in college learners' English autonomous learning and proposed that teachers should play a leading role in cultivating and promoting learners' autonomous learning. Without the teacher's introduction, it is difficult for learners' autonomous learning to achieve results.[4] Professor Zhang (2018) introduced 
the application of online autonomous learning platform, pointed out the existing problems, and gave suggestions and countermeasures.[5] Professor Fan and Zhu (2018) demonstrated that the construction and application of college English online learning platform has a significant assistance and positive impact on the improvement of vocational college learners' English autonomous learning ability. [6] Scholars Li and Chen (2019) effectively integrate modern network information technology with business English course teaching, and schools and teachers should scientifically design curriculum system and teaching content.[7] However, some people still worry about the current status of learners' online autonomous learning as they point out that learners' extracurricular autonomous learning status and learning effect are not optimistic due to the influence of learning environment. The previous studies investigated the application and efficiency of network-based autonomous learning platform in colleges. However, there is few researchers did research on the efficiency and countermeasures on the application of the platform based on questionnaire survey. Besides, the research objects have been restricted within students in colleges and universities. Taking the vocational college English learners in researcher's vocational college as a research example, this paper makes a study on the current status and efficiency of learners using the networkbased autonomous learning platform based on questionnaire survey.

\section{Research design}

\subsection{Research participant}

The research participants are the first year vocational college English learners who have been engaging in Extracurricular Autonomous Learning platform for one semester. The learners were required to log into the college's Blue Pigeon Network-based Autonomous Learning Platform for autonomous learning when they entered the college as freshmen. Blue Pigeon Network-based Autonomous Learning Platform is a network-based autonomous learning system. learners can log into the platform in the school's autonomous learning center, or log into the platform with any computers in the dormitory or library. They are required to study on it for 2 hours a week, and the learning content is regulated and optional. learners' autonomous learning after class will account for $50 \%$ of their regular scores which will account for $40 \%$ of the final total scores. That is to say, learners have to log into the network platform for autonomous learning after class in order to achieve satisfied marks. Their language teachers are mainly responsible for the specific learning content and learning supervision.

\subsection{Research questions}

This study mainly tends to answer the following three questions:

- What is the current status of learners using autonomous learning platform after class?

- What is the learners' evaluation on the using effect of self-learning platform?

- What are learners' opinions and suggestions on school autonomous learning and relevant regulations?

\subsection{Research tool}

In terms of the above research problems, the researcher developed a questionnaire in which one question item is made for one question.

- Whether you actually use the autonomous learning platform for learning after class;

- Your evaluation of the effect of using the autonomous learning platform;

- Improvement measures of the autonomous learning platform; 
In order to listen to the learners' voice, there is an open question for short answer at the end of the questionnaire which requires learners to put forward subjective opinions and suggestions to the autonomous learning platform and relevant rules and regulations of the school.

\subsection{Research procedure}

The questionnaire is carried out through network survey, which is carried out through the questionnaire function of the Blue Pigeon Autonomous Learning Platform. The specific survey time designed from April $6^{\text {th }}, 2021$ to April $16^{\text {th }}, 2021$. The platform will automatically pop up a questionnaire after learners logged into the platform. The questionnaire description clearly tells the learners that the questionnaire is anonymous, and the questionnaire results are only for scientific research. The main purpose of the questionnaire is to provide a reliable basis for the college to formulate relevant learning policies. Whether or not to participate in the questionnaire is decided by the learners themselves according to their personal decision. In order to ensure that every student is aware of the questionnaire, the researcher asked teachers to publicize the questionnaire in class. A total of 289 learners (with slightly different number of participants for each question) participated in the survey. After the formal completion of the questionnaire, the researcher conducted statistical analysis on the questionnaire. In order to deeply understand the relationship between learners' options and personal English foundation, the researcher obtained the scores of Practical English Test for Colleges, short for PRETCO) of the learners from the school administration department. PRETCO is a very authentic and popular test for vocational colleges to evaluate learners' English efficiency level, and the score range of PRETCO is from 0 to 100 with passing mark of 60 . Researcher used the batch query function of Excel to query and analyze the PRETCO scores of the learners participating in the questionnaire.

\section{Statistical analysis on the using effect of platform}

The researcher used a SPSS 22.0 statistical software to make statistics on the survey results of the number of platform users and the use effect of the platform. The results are shown in the cross table data in table 1.

Table 1. Cross table of percentage of users and percentage of use effect (Number: 289)

\begin{tabular}{|c|c|c|c|c|c|c|}
\hline & & Number and & percentage of use & & & \\
\hline & & Very useful & Certain effect & useless & & total \\
\hline $\begin{array}{l}\text { Percentage } \\
\text { of users }\end{array}$ & $\begin{array}{l}\text { Study every } \\
\text { week }\end{array}$ & & 52 & & 10 & $\begin{array}{c}110 \\
(42.47 \%)\end{array}$ \\
\hline & $\begin{array}{l}\text { Occasionally } \\
\text { used }\end{array}$ & & 116 & & 16 & $\begin{array}{c}140 \\
(48.44 \%)\end{array}$ \\
\hline & Seldom use & & 8 & & 18 & $\begin{array}{c}30 \\
(10.38 \%)\end{array}$ \\
\hline Total & & $\begin{array}{c}60 \\
(20.76 \%)\end{array}$ & $\begin{array}{r}176 \\
(60.89 \%)\end{array}$ & $\begin{array}{c}32 \\
(11.76 \%\end{array}$ & & 289 \\
\hline
\end{tabular}

Researcher conducted a Chi square test on the survey results of the number of 
platform users and the use effect of the platform to test whether there is a correlation between the two survey data. The results are shown in table 2 .

Table 2. Chi square test

\begin{tabular}{lrrrr}
\hline & value & freedom & \multicolumn{2}{c}{$\begin{array}{c}\text { Asymptotic significance } \\
\text { (bidirectional) }\end{array}$} \\
\hline Pearson Chi square & 143.823 & 4 & .000 \\
& a & 4 & .000 \\
Likelihood ratio & 122.121 & 1 & .000 \\
Linear correlation & 84.424 & 289 & & \\
Number of valid cases & 28 & & \\
\hline
\end{tabular}

a. Two cells (22.1\%) had an expected count of less than 5. The minimum expected count was 2.35 .

From the chi square test results in table 2, it is clear that the $\mathrm{P}$ value of chi square test is 0.000 , less than 0.05 , the survey data is significant, and it shows that the row variables and column variables are not mutually independent, that is, the percentage of use effect and the percentage of users are not independent, but related.

Table 3. symmetry measures

\begin{tabular}{|c|c|c|c|c|c|}
\hline & & Value & $\begin{array}{l}\text { Asymptotic } \\
\text { standard error }\end{array}$ & $\mathrm{T}^{\mathrm{b}}$ last read & $\begin{array}{l}\text { Significance of last } \\
\text { read }\end{array}$ \\
\hline \multirow[t]{2}{*}{$\begin{array}{l}\text { Name } \\
\text { name }\end{array}$} & to Phi & $\begin{array}{r}.74 \\
1\end{array}$ & & & .000 \\
\hline & Cramer V & $\begin{array}{r}.52 \\
1\end{array}$ & & & .000 \\
\hline $\begin{array}{l}\text { Interval } \\
\text { interval }\end{array}$ & to Pearson's R & $\begin{array}{r}.56 \\
2\end{array}$ & .047 & 11.164 & $.000^{\mathrm{c}}$ \\
\hline Order to order & $\begin{array}{l}\text { Spearman } \\
\text { correlation }\end{array}$ & $\begin{array}{r}.56 \\
0\end{array}$ & .047 & 10.910 & $.000^{\mathrm{c}}$ \\
\hline \multicolumn{2}{|c|}{ Number of valid cases } & $\begin{array}{r}28 \\
9 \\
\end{array}$ & & & \\
\hline
\end{tabular}

a. There is no null hypothesis.

b. The null hypothesis is assumed using asymptotic standard error.

c. Based on nominal approximation.

From the symmetrical measurement value in table 3 , Phi value is equal to $0.741, \mathrm{P}$ $=0.000$, indicating that there is a positive correlation between the percentage of users and the percentage of use effect, that is, the higher the percentage of users, the higher the percentage of use effect. The value of Cramer V is less than. 0005, which also shows the same result.

\section{Analysis and discussion}

From the data of the use effect and number of self-learning platform in Table 1: only $20.76 \%$ of the learners said "very useful", $60.89 \%$ of the learners chose "have a certain role", and $11.76 \%$ of the learners still chose "completely useless". The total percentage of learners who choose "very useful" and "have a certain role" is over $80 \%$, which 
indicates that learners hold a positive attitude towards the effect of autonomous learning platform. From the statistics of PRETCO scores, learners with poor English foundation are more inclined to improve their basic English ability through autonomous learning platform. Most of the learners think that all aspects of the autonomous learning platform should be improved. In fact, the network autonomous learning platform of college is still in the initial stage of operation. All aspects are not perfect, and all rules and regulations have not been established. This is the focus of the next step.

Then the researcher collects the improvement measures proposed by learners, and provide five alternatives, as shown in Table 4

\begin{tabular}{|l|l|l|l|l|l|}
\hline & $\begin{array}{l}\text { Richer } \\
\text { learning } \\
\text { resources }\end{array}$ & $\begin{array}{l}\text { Strengthen } \\
\text { management } \\
\text { and guidance }\end{array}$ & $\begin{array}{l}\text { Simplify } \\
\text { study content }\end{array}$ & $\begin{array}{l}\text { More } \\
\text { learning } \\
\text { materials }\end{array}$ & $\begin{array}{l}\text { Materials } \\
\text { can be } \\
\text { downloaded }\end{array}$ \\
\hline Numbers & 194 & 120 & 104 & 66 & 30 \\
\hline Percentage & $67.12 \%$ & $41.52 \%$ & $35.98 \%$ & $22.83 \%$ & $10.38 \%$ \\
\hline
\end{tabular}

Table 4. Suggestions for using autonomous learning platform (Number: 289)

According to table $4,67.12 \%$ of the learners choose to "provide rich learning resources", which shows that the learners' demand for learning resources is the first. The biggest difference between the blue pigeon Online Autonomous Learning Platform and the web-based online course developed by the publishing house is that the online course has existing learning materials, and teachers do not need or can not add various learning materials, that is to say, network course is a closed resource learning platform.

The percentage of choosing "teachers should strengthen the management of the platform and guide learners" accounted for $41.52 \%$, which indicated that learners' autonomous learning in the autonomous learning platform needed teachers' participation. Some studies have pointed out that at present, the autonomous learning ability of college learners in China is still at a low level, and they can not completely leave the guidance of teachers for autonomous learning [8] [9]. Professor Guo (2008) pointed out that teachers are an important factor affecting college learners' English autonomous learning, and teachers have an unshirkable responsibility and obligation in cultivating learners' autonomous learning ability [3:120]. Teachers should train learners' autonomous learning ability in classroom teaching.

$35.98 \%$ of the learners put forward the idea of "fragmenting the learning content to facilitate learning". This suggestion is related to the accelerating pace of learners' learning and life. learners hope to use the fragmenting time to learn. And $22.83 \%$ of the learners asked to "add the information of PRETCO". It shows that some learners hope to get help in exam materials. The construction of the database should follow the "three centers" principle, which is student-centered, interest centered and comprehensive application ability centered.

The open-ended survey allows learners to put forward their subjective opinions and suggestions on the autonomous learning platform of the college. A total of 160 learners participated in the survey. learners' suggestions can be summarized into the following categories: rules and regulations, learning materials, hardware construction, and suggestions for teachers. The details are as follows:

- Rules and regulations:

Strengthening the management of autonomous learning platform. The platform should increase more listening practising time and more English movies; I hope that I can get more scores for my usual performance because I am also learning listening and reading on the platform; Let learners take the initiative to learn, not just to learn English 
for the scores passively, which can improve the enthusiasm of learners, so the learning effect will be improved; It's not very good to study things that are too compulsory;

At present, the interaction of autonomous learning platform is not enough. When learners encounter problems in the process of autonomous learning, they have no way to communicate with teachers timely. Therefore, when formulating rules and regulations, teachers should also be required to participate in the process of learners' autonomous learning.

- Studying materials:

Adding more English movies. Some learning difficulties should be explained in detail; The platform should add more abundant learning resources to our autonomous learning platform, so that the resources of the platform will not be too monotonous; We can watch movies and listen to songs on the independent platform, which will be more dynamic, and the learning effect will be better. Updating foreign language broadcasting tools, such as BBC; I hope that the proportion of time spent on watching movies should be lengthened.

In sum, it is necessary to increase and diversifying the learning materials from time to time, and it is also necessary to put more PRETCO learning materials on it. The excellent open courses at home and abroad can also be introduced into the autonomous learning platform system, so that learners can fully enjoy all kinds of excellent teaching resources in the process of autonomous learning, and foreign language teaching can also be extended after class.

- Hardware construction:

Establishing Android version for mobile phone, so that learners can use their mobile phones to use platform independently anytime and anywhere without being restricted by learning sites and time; There are problems with autonomous learning platform, and sometimes we even can not log on it; I hope the college can strengthen the maintenance and management of the system.

Some learners, especially some impoverished learners, have not bought personal computers, so they can only study in the autonomous learning classroom of the college. However, at present, the number of autonomous learning classrooms can not fully meet the needs of learners' autonomous learning, therefore, it is necessary to increase the number of autonomous learning rooms.

- Suggestions for teachers:

I hope teachers should improve learners' understanding of the function of the platform, rather than simply let learners to use it completely independently; It's good to have a teacher to guide them online; To strengthen the communication between learners and teachers on how to use the platform.

An English communication channel between learners and teachers should be added to the autonomous learning system, so that learners can communicate with teachers at any time in the process of autonomous learning.

\section{Conclusion and countermeasures}

This paper makes a survey on the current situation of vocational college English learners' using of network-based autonomous learning out of class. The results show that learners hold a positive attitude toward the network-based extracurricular English autonomous learning, and learners with different English levels hold different views toward networkbased Extracurricular Autonomous Learning platform. It is not enough just to rely on 
regulations alone to mobilize the learners' enthusiasm for autonomous learning through the network platform after class,

First, teachers should be organized to participate the learning database in the platform to meet the personalized learning needs of learners. Autonomous learning database is the premise of learners' autonomous learning through the network platform. What resources should be collected in the database and whether there are learning resources that learners are interested in are important guarantee for learners to log into the platform for learning actively. Network-based autonomous learning platform is an open platform, therefore, in addition to its own learning resources, teachers should put various college-based learning resources according to learners' actual needs.

Second, teachers should actively participate in learners' autonomous learning ability training, learning strategy training and supervision and management. Many studies have shown that Chinese college learners' English autonomous learning level and ability are still at a low level therefore it is impossible to achieve success in extracurricular autonomous learning without teachers' participation. On the basis of hardware conditions, whether teachers participate in autonomous learning or not is a decisive factor affecting the success or failure of autonomous learning. Without teachers' active participation, autonomous learning is likely to face failure. Therefore, teachers must participate in learners' autonomous learning, supervise, guide and train learners' extracurricular autonomous learning.

Third, formulating relevant policies to support autonomous learning. The administrative departments should formulate policies to arouse the enthusiasm of teachers and learners. Only by mobilizing the enthusiasm of teachers and learners, can extracurricular network autonomous learning be implemented because the college's policy has a guiding and even decisive role. The formulation of the policy is mainly divided into two directions: To formulate relevant autonomous learning policies for learners to ensure their autonomous learning after class. According to the specific situation of the hardware equipment, college has carried out policy provisions on learners' autonomous learning, that is, they must study for 2 hours in the autonomous learning platform every week, which is one of the important sources of their score of regular performance. Compared with that of learners, the policy-making for teachers can not solve the problem with only a inflexible regulation, but should has certain incentive policies or workload regulations. Some teachers even think that guiding learners' autonomous learning is a kind of "extra work". Of course, this idea is not right. However, Participating in learners' extracurricular autonomous learning really increases the workload of teachers. Whether this part of the workload can be recognized or not and how to be recognized is an urgent issue for policy makers.

Fourth, providing special education technology training for teachers. The premise for teachers to participate in autonomous learning based on network platform is that teachers should have a certain computer and network foundation. It must be admitted that many English teachers have weak computer foundation, which still can not meet the needs of guiding learners' learning. Therefore, it is necessary to carry out special training for teachers to use the network platform.

At last, setting up special teaching research and teaching reform projects to encourage teachers to carry out teaching research based on network platform. The educational administration department of the college should conduct special research projects to encourage teachers to carry out teaching and research based on network autonomous learning platform. At present, the network-based teaching mode is very popular around the world, and attracts many people's attention. "Flipped classroom" and 
"MOOC" have been widely accepted. The educational administration department should encourage English teachers to carry out "Flipped classroom", "MOOC"and other teaching practices based on the network autonomous learning platform.

\section{Acknowledgment}

2021 Guangdong Education Science Planning Project (Special program for Higher Education) "Research on SPOC-based Blended Learning Adaptability of Higher Vocational English Learners" (Grant No: 2021GXJK558).

\section{References}

[1] Department of higher education. Ministry of education, requirements for College English teaching, Shanghai Foreign Language Education Press, 2007.

[2] Wang L., Cui C., Implementing the "business English undergraduate teaching guide" and promoting business English talent training, Foreign language circles, 2020.vol.3, p.5-11.

[3] Zhu Y., Current situation and Countermeasures of English autonomous learning of non English majors, Journal of Southeast University, vol.3, p.5-11, 2011.

[4] Guo J., The guiding role of teachers in college students' English Autonomous Learning, Journal of Capital Normal University, 2008.vol.3, p.122-125.

[5] Zhang J.. Current situation and existing problems of College English network platform, Horizon of science and technology, 2018.vol.9, p:180-183.

[6] Fan W., Zhu Q., Research on the application and teaching practice of College English Online Autonomous Learning Platform, Journal of Guangdong Communications vocational and technical college, 2018.vol.12, p76-78.

[7] Li Y., Chen X., Xue X., Huang Y.. Analysis of the current situation and reform of network information teaching of business English, Education and teaching forum, 2019.vol.12, p.136-138.

[8] Fu X., A survey of College Students' English autonomous learning ability and problems, Journal of Hainan University, 2006.vol.1, p.143-146.

[9] Gao Ch., Guo J., An investigation and Research on the current situation of College Students' Autonomous English Listening Learning, Journal of Panzhihua University, 2011.vol.1, p.91-94. 